\title{
Preliminary study of non-methanogenic hydrogenotrophic microflora in the rumen of newborn lambs
}

\author{
J Doré, F Rieu-Lesme, G Fonty, P Gouet
}

INRA, CR de Clermont-Ferrand-Theix, Laboratoire de Microbiologie, 63122 Saint-Genès-Champanelle, France

Hydrogen is an important intermediate in the rumen ecosystem. Produced by numerous bacterial, fungal, and protozoal species, it serves as electron donor in the reduction of $\mathrm{CO}_{2}$ to methane. The replacement of methanogenesis, which constitutes a loss of energy for the ruminant, by alternative hydrogenotrophic pathways has been proposed as a strategy to improve utilization of feed energy by the animal. In this context, and based on previous results (Fonty et al, 1987), we have initiated an investigation of the hydrogen-utilizing microflora potentially present in the rumen prior to the establishment of methanogens.

Rumen contents were sampled from lambs kept in sterile isolators 1 day after birth and associated with the rumen microflora of 2,3 or $\mathbf{5}$ day-old flock-reared lambs. Hydrogen utilization experiments were performed using washed rumen bacteria in anaerobic dilution solution under $\mathrm{H}_{2} / \mathrm{CO}_{2}$ or $\mathrm{N}_{2} / \mathrm{CO}_{2}$ (4:1) gas at initial overpressure of 0.5 bars. Incubations were at $39{ }^{\circ} \mathrm{C}$ on a rocking agitator. The incorporation of ${ }^{13} \mathrm{C}$ - or ${ }^{14} \mathrm{C}$-labeled $\mathrm{CO}_{2}$ was followed. Pure cultures of $\mathrm{H}_{2}$-utilizing bacteria were obtained by repeated streaking, transfers and final isolation from roll-tubes using a medium (Balch et al, 1979) containing $30 \%$ rumen fluid.
A production of methane from $\mathrm{H}_{2} / \mathrm{CO}_{2}$ was observed for the microflora of 2-day-old lambs or older. No methane was produced by $24 \mathrm{~h}$ microflora, while an $\mathrm{H}_{2}$-dependent incorporation of $\mathrm{CO}_{2}$ took place (table I). The ${ }^{14} \mathrm{CO}_{2}$ label was primarily incorporated in the VFA fraction $(86 \%)$. This was absent after a treatment killing all bacteria $\left(80^{\circ} \mathrm{C}\right.$, $30 \mathrm{~min}) .{ }^{13} \mathrm{C}$ NMR showed that double labeled acetate was the major product. Strains of hydrogen-utilizing bacteria were isolated from the $24 \mathrm{~h} \mathrm{mi-}$ croflora. These were pleiotrophic and produced acetate as the main fermentation product.

We propose data supporting the hypothesis that hydrogenotrophic bacteria pre-exist in the rumen prior to the establishment of methanogens. These are able to use $\mathrm{H}_{2}$ to reduce $\mathrm{CO}_{2}$ to soluble products.

Balch WE, Fox GE, Magrum LJ, Woese CR, Wolfe RS (1979) Microbiol Rev 43, 260296

Fonty G, Gouet Ph, Jouany JP, Senaud J (1987) J Gen Microbiol 133, 1835-1843

Table I. Fermentation products of rumen bacterial suspensions incubated in vitro for $24 \mathrm{~h}$.

\begin{tabular}{cccrcccc}
\hline Lamb & $\begin{array}{c}\text { Microfloral } \\
\text { lambs aged }\end{array}$ & $\begin{array}{c}\text { Incubation } \\
\text { under }\end{array}$ & \multicolumn{5}{c}{ Fermentation products (mM) } \\
& & & Acetate & Propionate & Butyrate & Valerate \\
\hline & & $\mathrm{N}_{2}: \mathrm{CO}_{2}$ & 0.0 & 28.7 & 8.7 & 2.6 & 1.1 \\
$\mathrm{H}$ & $24 \mathrm{~h}$ & $\mathrm{H}_{2}: \mathrm{CO}_{2}$ & 0.0 & 49.2 & 10.7 & 3.0 & 1.1 \\
B & $48 \mathrm{~h}$ & $\mathrm{~N}_{2}: \mathrm{CO}_{2}$ & 1.4 & 27.5 & 9.4 & 2.0 & 1.0 \\
\hline
\end{tabular}

